\title{
MARKETING STRATEGY FORMATION FOR THE DEVELOPMENT OF ORGANIC PRODUCTION IN THE UKRAINE
}

\author{
Volodymyr Ivanyshyn, $\mathrm{PhD}^{1}$; Oleg Kucher, $\mathrm{PhD}^{2}$; Tetyana Bilyk, $\mathrm{PhD}^{3}$ \\ ${ }^{1}$ Faculty of Agricultural Technologies and Environmental Management, State Agrarian and Engineering University \\ in Podilya \\ ${ }^{2,3}$ Faculty of Economics, State Agrarian and Engineering University in Podilya
}

\begin{abstract}
The article examines the state and prospects of organic production by agricultural enterprises in the Ukraine. Existing natural, climatic and soil potential for the production of organic agricultural products as well as their export and consumption in the domestic market are characterized. It was noted that the development of organic production is one of the main priorities of the agrarian sector of the Ukrainian economy. State support for the development of this type of production is being implemented, as reflected in ' $3+5$ ' as a strategy for the development of the agrarian sector of the economy for the period until 2020. Attention is drawn to the instability of the environment, insufficient development of demand and limitations of financial resources, which hinder the realization of Ukraine's potential in this segment of the agrarian sector. The conclusion on the necessity of applying marketing strategies for promoting and marketing organic products on domestic and foreign markets is drawn. The model of forming a marketing strategy of organic production development in the Ukraine is offered.
\end{abstract}

Keywords: marketing strategies, organic production, organic product sales, government support JEL code: M31

\section{INTRODUCTION}

The current problem of organic production development in the Ukraine stems from the deterioration of the ecological situation in the world, thus organic products are gaining popularity. Simultaneously, considerable attention is paid to food products, the consumption of which benefit human health. Domestic consumers are striving to improve the quality and safety of food products. The development of organic production contributes to environmental, economic and social benefits of this area of activity. In addition to assessing the state of organic production, the goal is to develop marketing strategies for the development of the organic products' market. To achieve these goals, marketing strategies are given an important place in the management system of this area of activity. The main objective of the strategy is to increase sales, market share and profit.

\footnotetext{
${ }^{1}$ Corresponding author: Schevchenko 13, Kamianets-Podilskyi, Ukraine, v.v.ivanyshyn@gmail.com, +38067 4010003

${ }^{2}$ Corresponding author: Schevchenko 13, Kamianets-Podilskyi, Ukraine, kucheroleg68@gmail.com, +380979006032

${ }^{3}$ Corresponding author: Schevchenko 13, Kamianets-Podilskyi, Ukraine, tanyabilyk12@gmail.com, +38067 7824213
} 


\section{THEORETICAL BACKGROUND}

The study of domestic and foreign sources proves that in today's economic theory and practice, marketing development is a prerequisite for achieving a company's market goals. First of all, it concerns the production and sale of new types of goods, including organic products. The legal and economic basis for the production and circulation of organic agricultural products and raw materials in the Ukraine is determined by the Laws of Ukraine aimed at ensuring the proper functioning of the market for organic products and raw materials, as well as guaranteeing consumer confidence in the quality of products and raw materials, marked as organic (Law of Ukraine, 2013).

Comprehensive propaganda of values and outlooks, inherent to supporters of the world organic movement, increase the efficiency of agricultural production together with the simultaneous development of the modern world and domestic safety for natural and human technologies, thus promoting the development of the organic movement in the Ukraine, focusing more specifically on production, processing and export of organic products, as well as the formation of the domestic consumption market (Federation of Organic Movement of the Ukraine, 2010).

The only way to achieve the goals of an enterprise in terms of turnover, profit, and return on investment is to meet consumer concerns. Marketing, as a management function, has a special role in this process. Planning marketing strategies involves analysing a company's capabilities and making decisions about marketing activities and their implementation (Harkavenko, 2002).

\section{MATERIALS AND METHODS}

The following documents and materials are used to conduct research on the state of development of the organic production market in the Ukraine:

- materials of the Federation of Organic Movement of the Ukraine;

- materials from the Ministry of Agrarian Policy and Food of the Ukraine;
- materials of marketing research on the demand and supply of organic products in domestic and foreign markets.

In the course of this research, the following methodological approaches were used: materials of the Federation of Organic Movement of the Ukraine:

- materials from the Ministry of Agrarian Policy and Food of the Ukraine;

- materials of marketing research on the demand and supply of organic products in domestic and foreign markets.

In the course of this research, the following methodological approaches were used:

- study of consumer behaviour in the markets of organic products, enabling the determination of consumer needs, requirements and wishes.

- the method of system analysis giving insight into the market situation and enabling an estimation organic production development dynamics;

- the method of economic-mathematical modelling enabled the assessment of the prospects of developing the organic products' market and, taking into account existing factors of the external and internal environment, the development of a model for the formation of a marketing strategy for the development of organic production in the Ukraine.

\section{RESULTS AND DISCUSSION}

\section{Assessment of the state of production of organic products}

Organic production in the world, as a separate business, began with a small number of farmers producing clean, natural products for a particular circle of traditional consumers. For more than 80 years of existence, it has become a powerful international process, which includes not only the production of agricultural products, but also strictly controlled conservation, processing, transportation and sale (Federation of Organic Movement of the Ukraine, 2010).

The Ukraine has the largest area in Europe, where almost all land is suitable for agriculture. There are more than 41 million ha of agricultural land, of which about 8 million hectares of relatively clean soil. With significant natural, climatic and soil potential for organic agricultural production, its export and con- 
sumption on the domestic market, producers have achieved results in developing their own organic production (Pavlenko, 2016).

According to the Ministry of Agrarian Policy and Food (Baker Tilly, 2018), as of 2017 in the Ukraine, the total area of agricultural land certified as organic is 421.5 thousand ha (Fig. 1). Almost half of organic land $(48.1 \%)$ is occupied by grain crops, which places the Ukraine in seventh place among producers of organic grains. More than $16 \%$ is covered by oil - fifth place in the world; $4.6 \%$ by beans - seventh place; vegetables cover $2 \%$ of the land - 10th place; fruit $-0.6 \%$, and grapes $-0.1 \%$. Among other crops that cover $28.6 \%$ of land, mustard, flax, nuts and berries, etc., are grown.

According to Organic Standard, as of 20 August 2017, 485 entrepreneurs received a certificate of organic production in the Ukraine, of which 244 are engaged in plant production. Recently, a considerable part of new certification pertain to the production of niche crops, including raspberries and other berries (Agropolit, 2018).

According to research conducted, since 2006 there is a tendency to actively fill the domestic market with own organic products at the expense of establishing own processing of organic raw materials. Within 11 years it has increased from EUR 400 thousand in 2006 to EUR 21.2 million in 2016 (Kovalchuk and Mandro, 2017).
Support for organic production is one of the main priorities reflected in the agrarian sector development called ' $3+5$ ', as a strategy for the agrarian sector of the Ukraine's economy until 2020 (Ukrainian government portal, 2016).

\section{Formation of marketing strategy for the development of organic production}

Organic agricultural production is the most sustainable agricultural sector model. Within the implementation of the Law of Ukraine on the Production and Circulation of Organic Agricultural Products and Raw Materials, great attention should be paid to the formation of a holistic, scientifically sound system of organization and management of enterprises producing organic products (Law of Ukraine, 2013).

Such a system could be reflected in the marketing management of enterprises that meets the needs and demands of the market, responds to changes in a flexible and adequate way in an external and internal market environment as well as increases the profitability of production and activities of the enterprise as a whole.

The effective introduction and use of marketing at organic enterprises of the Ukraine requires, first of all, the proper definition of a general programme of actions of enterprise production. The development and implementation of a marketing strategy in the management of organic production of enterprises is a vital

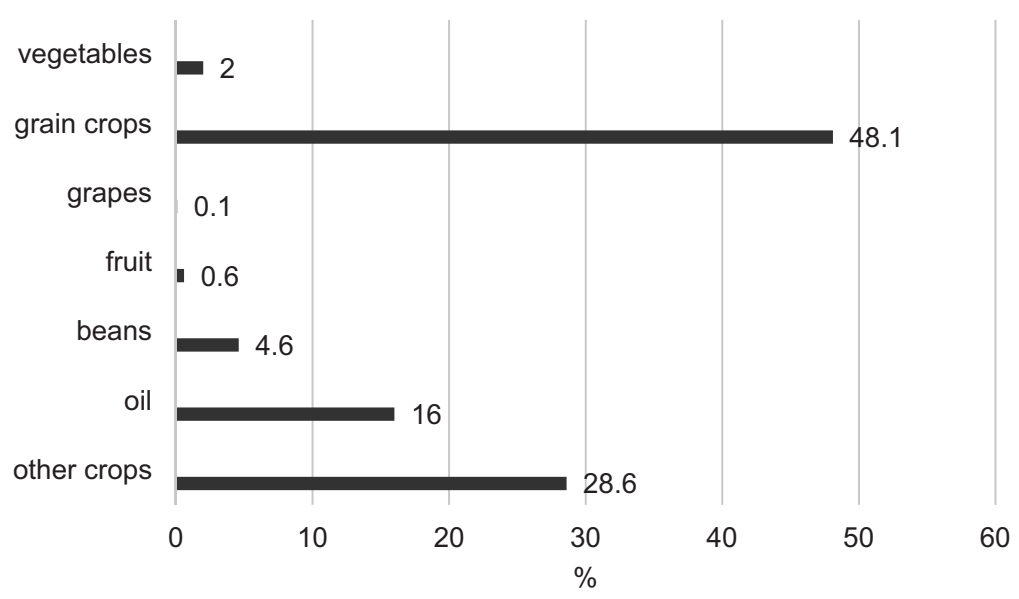

Figure 1. Areas of organic agricultural land (421.5 thousand ha) in terms of crops Source: author's own research based on Baker Tilly (2018). 
need for the functioning of domestic agricultural producers (Kucher, 2011).

The theory of marketing has evolved, and in practice, models of making strategic decisions are used. Each model embodies a certain approach to developing marketing strategies. The determination of marketing objectives makes it possible to decide on the choice of marketing strategies to achieve these goals (Harkavenko, 2002).

Research has shown that the effective development of the organic product' market involves the organization of production and marketing on the basis of a system of marketing techniques and tools. For the effective production and sale of organic produce by agrarian enterprises, a model for forming a marketing strategy for the development of organic production in the Ukraine is proposed (Fig. 2).

1. The strategy of market coverage involves the placement of goods in the distribution network using intensive and selective distribution.

Intensive distribution involves the placement and sale of goods through the largest possible number of retailers. At present, the implementation of or- ganic products is carried out through specialized departments of supermarkets and small stores in Kyiv, city-millionaires and regional centres. These are supermarkets, small specialized stores, and on-line stores where consumers can get product information and make orders. Given the increase in demand, it is necessary to increase the number of places where organic products can be purchased (Kosar and Kuzo, 2016).

Selective distribution involves the conclusion of an agreement with the manufacturer not with all intermediaries, but with those who are interested in the implementation of the product. To achieve this, it is necessary to thoroughly investigate demand on domestic and foreign markets for organic products, to ensure effective sales and profit.

2. The strategy of intensive growth includes the choice of growth directions where, depending on sales, the following options are used: the strategy of deep penetration into the market; market development strategy and product development strategy.

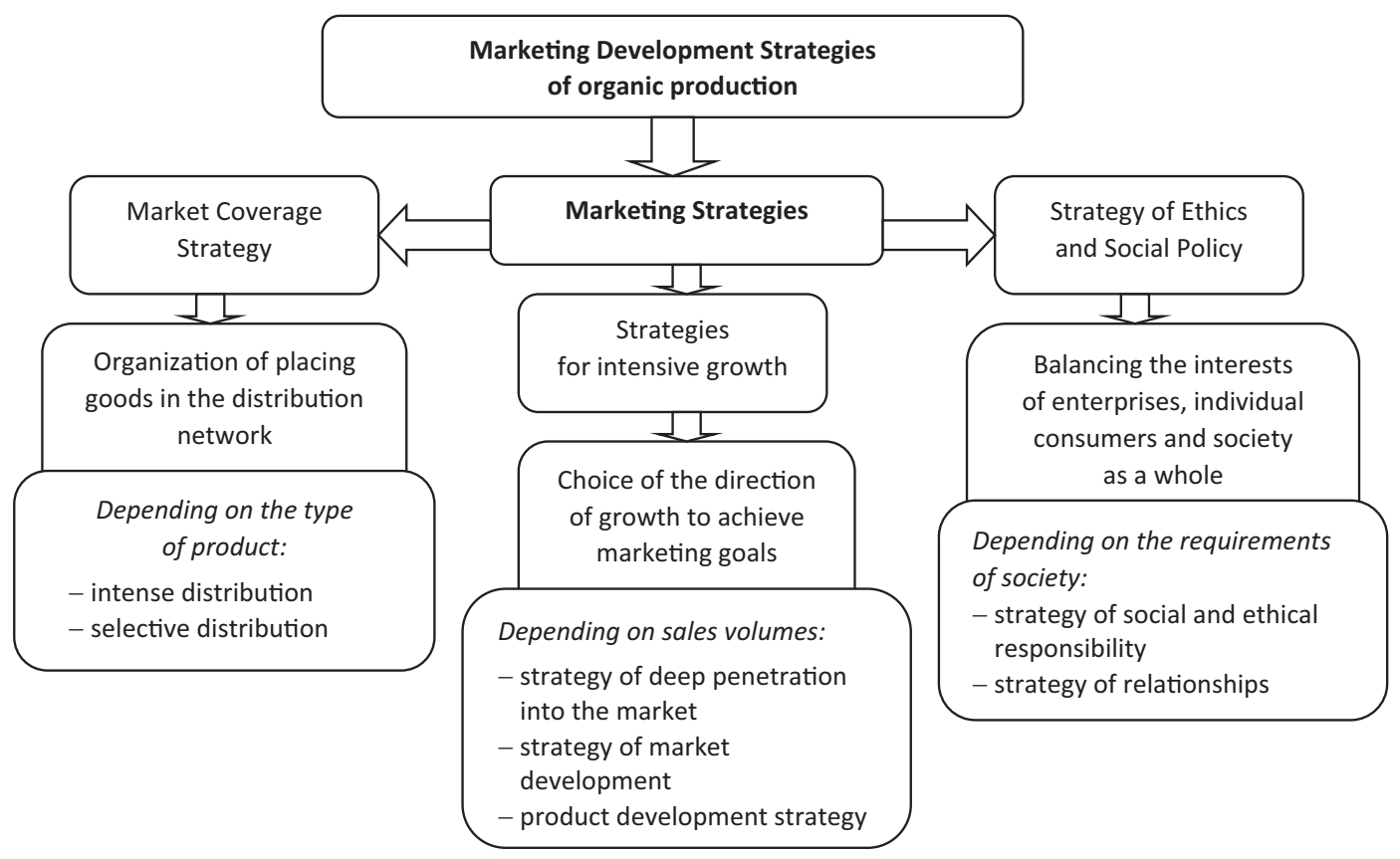

Figure 2. Model of formation of a marketing strategy for the development of organic production in the Ukraine Source: author's own work. 
The strategy of deep penetration into the market implies an increase in sales volume, market share and profits on existing markets due to available goods. To do this, it is necessary to promote the product in order to increase the desire of existing consumers and entice new customers who have not yet used the product, and convince consumers to use a larger amount of goods. An important channel for the marketing of organic products should be specialized stores of healthy eating.

The market development strategy implies the company's penetration into new markets by identifying new areas of product use, entering new segments of the market, new territorial markets and offering goods through new sales channels. In addition, it is necessary to form future markets that do not yet exist, but need to be presented and created for specific products.

The product development strategy implies an increase in sales as a result of introducing new goods in existing markets. A promising direction for the supply of new organic products is niche crops. The most demanded niche products, both in the domestic market and European Union market, are sorghum, spices, nuts and berries, fresh herbs, and garlic.

3. The strategy of ethics and social policy is responsible for balancing the interests of enterprises, individual consumers and society as a whole, and includes the following areas: a strategy of social and ethical responsibility and a strategy of interactions.

The solution of this issue is reflected in the principles of organic agriculture. They are composed of ethical principles and include the principle of health, the principle of ecology, the principle of justice and the principle of care (Organic UA, 2010).

The principle of health implies that organic agriculture must support and improve the health of soil, plants, animals, people and the planet as a single and indivisible whole.

The principle of ecology means that the impact on the environment should be reduced through efficient material and energy management in order to maintain and improve the environmental qual- ity of products and resources. Organic farming should be based on the principles of natural ecological systems and cycles, working, co-existing with and supporting them.

The principle of justice is based on the notion that the production of organic products should be based on a relationship guaranteeing equity, taking into account the interests of the environment and living conditions. Justice is characterized by objectivity, respect, correctness and economic attitude, both between people and in relations with other living beings.

The principle of care argues that organic farming management should have a preventive and responsible nature to protect the health and well-being of both present and future generations and the environment. Therefore, new technologies have to undergo a system of evaluation, and existing methods require constant review and, if necessary, appropriate measures need to be taken.

The proposed strategies allow producers of organic products to take into account the requirements of the market environment. The organic products' market is a promising segment of the agro-industrial market. This is an incentive for the development of organic farming and the cultivation of organic produce by Ukrainian farmers.

\section{CONCLUSIONS}

In recent years, the Ukraine has followed world trends and is developing organic production. Conducted research has shown that effective production of organic products should, first of all, be based on systematic and objective research and the formation of marketing strategies for its development. In order to increase the demand for organic products, it is necessary to implement an effective marketing policy, to stimulate its development and organize production in accordance with all international requirements and standards. For the effective production and sale of organic products by agrarian enterprises, the authors developed a model for forming a marketing strategy for the development of organic production in the Ukraine. 


\section{REFERENCES}

1. Agropolit (2018). Analysis of organic products market in Ukraine. Retrieved from: https://agropolit.com/spetsproekty/407-analiz-rinku-organichnoyi-produktsiyi-vukrayini [Accessed 15.02.2018].

2. Baker Tilly (2018). Organic production in Ukraine is confidently moving forward. Retrieved from: www. bakertilly.ua/ua/news/id1402 [Accessed 12.02.2018].

3. Federation of Organic Movement of Ukraine (2010). Organic in Ukraine. Retrieved from: http://www.organic.com.ua/uk/homepage/2010-01-26-13-34-50 [Accessed 26.01.2010].

4. Harkavenko, S. (2002). Marketing: under the arm. Libra, Kyiv.

5. Kosar, N., Kuzo, N. (2016). The research of the market of the organic food. Effective Economy, 2. Retrieved from: Economy.nayka.com.ua/?op $=1 \& z=4777 \quad$ [Accessed 08.02.2016].

6. Kovalchuk, S., Mandro, A. (2017). Agroecological potential of Ukraine: Basis of organic production. Re- trieved from: http://socrates.vsau.org/reposit ory/getfile.php/13584.pdf [Accessed 27.04.2017].

7. Kucher, O. (2011). Formation of Marketing Strategy of Sales of Agroindustrial Enterprises. European University, Kyiv.

8. Law of Ukraine on Production and Circulation of Organic Agricultural Products and Raw Materials. Law of Ukraine on 3 September 2013, No 425-VII.

9. Organic UA (2010). Principles of organic agriculture. Retrieved from: http://organic.ua/uk/2010/05/1344pryncypy-organichnogo-silskogo-gospodarstva [Accessed 01.02.2010].

10. Pavlenko, O. (2016). Ukraine has chance to become an organic basket of the world. Retrieved from: https:// lb.ua/blog/opavlenko/326957_ukraina_maie_usi_shansi_stati.html [Accessed 02.02.2016].

11. Ukrainian government portal (2016). Ministry of Agrarian Policy presented a comprehensive plan for reforming the sector " $3+5$ ". Retrieved from: https:// www.kmu.gov.ua/ua/news/249048266 [Accessed 20.05.2016]. 